\author{
๑В. В. Овчарук, А. В. Бойчук, О. І. Хлібовська, В. Г. Дживак \\ ДВНЗ «Тернопільсъкий державний медичний університет \\ ілені І. Я. Горбачевсъкого МОЗ України»
}

\title{
КАРДІОТОКОГРАФІЧНІ ОСОБЛИВОСТІ У ЖІНОК ІЗ ЗАТРИМКОЮ РОСТУ ПЛОДА
}

КАРДІОТОКОГРАФІЧНІ ОСОБЛИВОСТІ У ЖІНОК ІЗ ЗАТРИМКОЮ РОСТУ ПЛОДА. НамИ проаналізовано особливості кардіотокограм у 30 вагітних жінок із затримкою росту плода. Контрольну групу склали 25 вагітних із фрізіологічним перебігом.

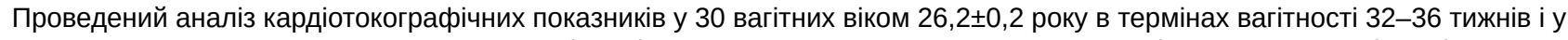
яких за результатами ультразвукового скринінгу діагностовано затримку росту плода. Кардіотокограми у вагітних із затримкою росту плода характеризуються достовірним зменшенням базальної частоти серцевих скорочень плода, пониженою амплітудою, зменшенням кількості акцелерацій, наявністю децелерацій. Ці дані свідчать про плацентарну диссункцію та хронічну внутрішньоутробну гіпоксію.

КАРДИОТОКОГРАФИЧЕСКИЕ ОСОБЕННОСТИ У ЖЕНЩИН С ЗАДЕРЖКОЙ РОСТА ПЛОДА. НаМИ ПроанаЛИЗИроваНЫ особенности кардиотокограмм у 30 беременных женщин с задержкой роста плода. Контрольную группу составили 25 беременных с фризиологическим течением. Проведенный анализ кардиотокографических показателей в 30 беременных в возрасте 26,2士0,2 лет в сроках беременности 32-36 недель, в которых по результатам ультразвукового скрининга диагностирована задержка роста плода. Кардиотокограммы у беременных с задержкой роста плода характеризуются достоверным уменьшением базальной частоты сердечных сокращений плода, сниженной амплитудой, уменьшением количества акцелераций, наличием децелераций. Эти данные свидетельствуют о плацентарной дисфункции и хронической внутриутробной гипоксии.

CARDIOTOCOGRAPHYA FEATURES IN WITH WOMEN FETAL GROWTH RETARDATION. We analyzed the features of cardiotocograms in 30 pregnant women with fetal growth retardation. The control group consisted of 25 pregnant women with physiological course. The analysis of 30 indicators cardiotocographic pregnant at the age of $26.2 \pm 0.2$ years pregnancy $32-36$ weeks in whom the results of ultrasound screening was diagnosed the growth retardation. Cardiotocgrams in pregnant women with fetal growth retardation are characterized by a significant decrease in basal heart rate of the fetus, reduced amplitude reduction in acceleration, deceleration availability. These data indicate placental dysfunction and chronic intrauterine hypoxia.

Ключові слова: вагітна, затримка розвитку плода, новонароджений.

Ключевые слова: беременная, задержка развития плода, новорожденный.

Key words: pregnant, newborn, intrauterine fetal, fetal growth retardation.

ВСТУП. Проблема зниження перинатальної захворюваності і смертності залишається головною медичною проблемою у всіх країнах світу. Одним із ускладнень вагітності є затримка росту плода (ЗРП), частота якої, за даними різних дослідників, коливається від 3,2 до 27,8 \% [1-3]. Затримка росту плода у вагітних характеризується високим рівнем анте- та інтранатальної смертності, захворюваності і смертності новонароджених в ранньому неонатальному періоді [1]. Згідно з теорією D. Barker, важливою є проблема фетального програмування соматичної патології в дорослому віці [2, 3]. Згідно з даною теорією, внутрішньоутробне страждання маловагового плода призводить до незворотних змін його обміну речовин та/чи будови внутрішніх органів, що в подальшому реалізується в таку хронічну патологію, як цукровий діабет, серцево-судинна патологія, захворювання нирок [4]. Роди у пацієнток із ЗРП потребують від акушерів і неонатологів підвищеної готовності до різноманітних ускладнень: ассріксії, порушень мозкового кровообігу, гнійно-септичних інфекцій та інших [5]. Дана проблема має також і гостре соціальне значення тому, що більше третини цих дітей в подальшому відстають у фрізичному і психомоторному розвитку, що потребує від суспільства та сім'ї моральних і матеріальних витрат [6]. Тому актуальною залишається проблема своєчасної діагностики й адекватного лікування та профрілактики перинатальних і постнатальних ускладнень затримки росту плода.
Мета роботи - визначити діагностичне та прогностичне значення кардіотокографії в оцінці матковоплацентарного кровообігу при затримці росту плода.

МАТЕРІАЛИ ТА МЕТОДИ. Проведено аналіз результатів кардіотокографії у 30 вагітних в термінах вагітності 32-36 тижнів, у яких, за результатами ультразвукового обстеження, діагностували затримку росту плода, та 25 вагітних із фрізіологічним перебігом вагітності.

Основну групу склали 30 пацієнток, вагітність у яких ускладнилась затримкою росту плода та була підтверджена в ранньому неонатальному періоді. Контрольну групу склали 25 вагітних із фрізіологічним перебігом вагітності, які народили живих доношених дітей з масо-ростовими характеристиками відповідно до гестаційного віку.

РЕЗУЛЬТАТИ ДОСЛІДЖЕННЯ ТА ЇХ ОБГОВОРЕННЯ. Вік вагітних склав $26,2 \pm 0,2$ в основній групі та 27,1 $\pm 0,1$ в контрольній групі. Термін вагітності 32-36 тижнів. Для зіставлення масово-ростових показників відповідно до гестаційного віку використовували перцентильні таблиці. 3 метою діагностики порушень стану плода проводили кардіотокографрію (КТГ). Даний метод діагностики полягає в оцінці серцевої діяльності плода. Формування кардіотонічного рефлексу плода завершується в 30 тижнів вагітності. Кардіотокограма - це одночасний запис маткових скорочень і серцевої діяльності плода. Даний метод дозволяє комплексно оцінювати реактивність (здатність до 


\section{Акушерство та гінекологія}

змін частоти серцевих скорочень під дією різних фракторів) серцевої діяльності плода. Для запису кардіотокограм використовували монітор стеження за станом матері та дитини Cadence Basic та фретальний монітор Qiston BT-350 LCD. Запис проводили протягом 30 хвилин.

Для аналізу кардіотокограм використовували шкалу W. Fisher та співавт., 1976. Оцінка у 8-10 балів відповідає нормальній КТГ, 5-7 балів вказують на початкові порушення стану плода, 4 бали і менше можуть вказувати на виражені порушення плода [7].
На рисунку 1 представлена кардіотокограма при

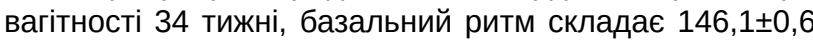
ударів за хвилину.

На представленій на рисунку 2 кардіотокограмі $127,4 \pm 0,2$ удари за хвилину, відмічається монотонний ритм, який характеризується зменшенням амплітуди та частоти осциляцій, зменшенням кількості акцелерацій.

Результати аналізу кардіотокограм представлені в таблиці 1.

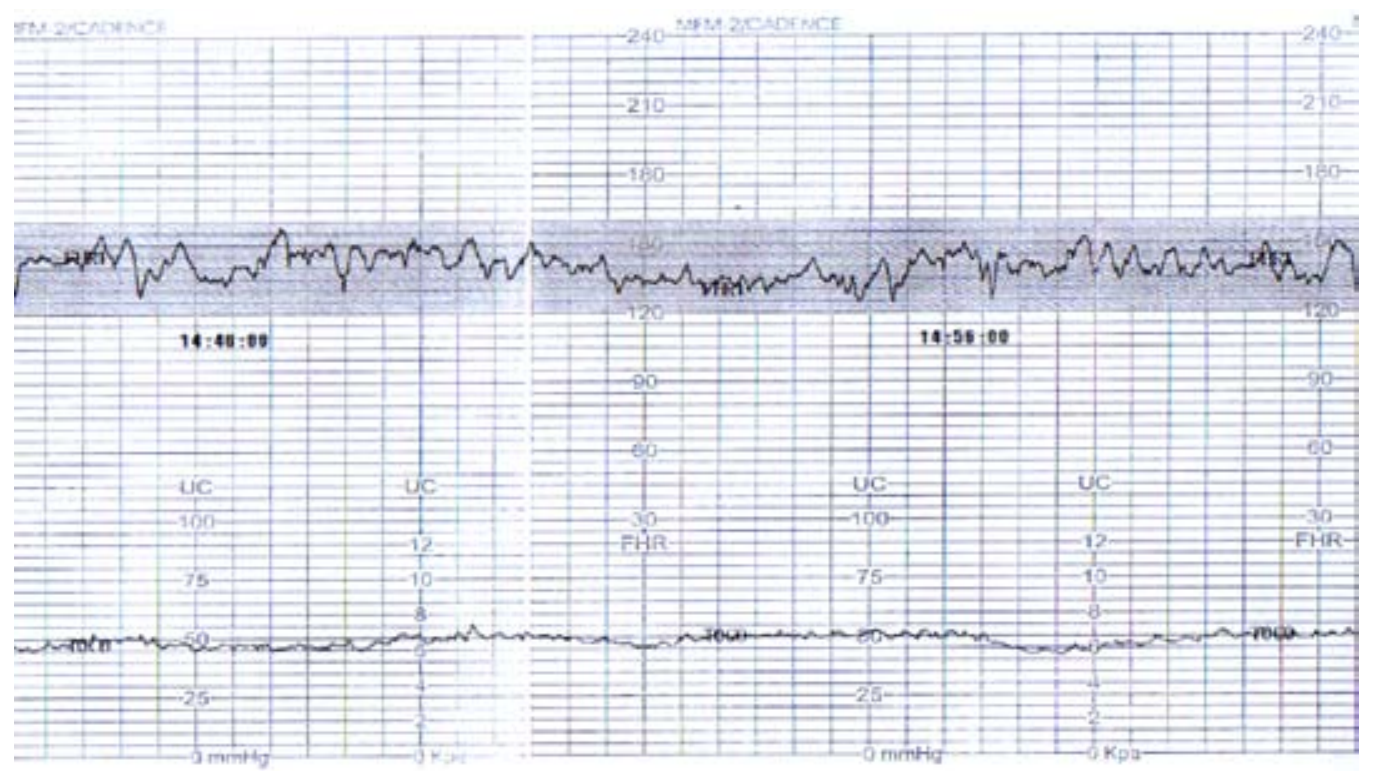

Рис. 1. Вагітність 34 тижні. Оцінка КТГ 9 балів.

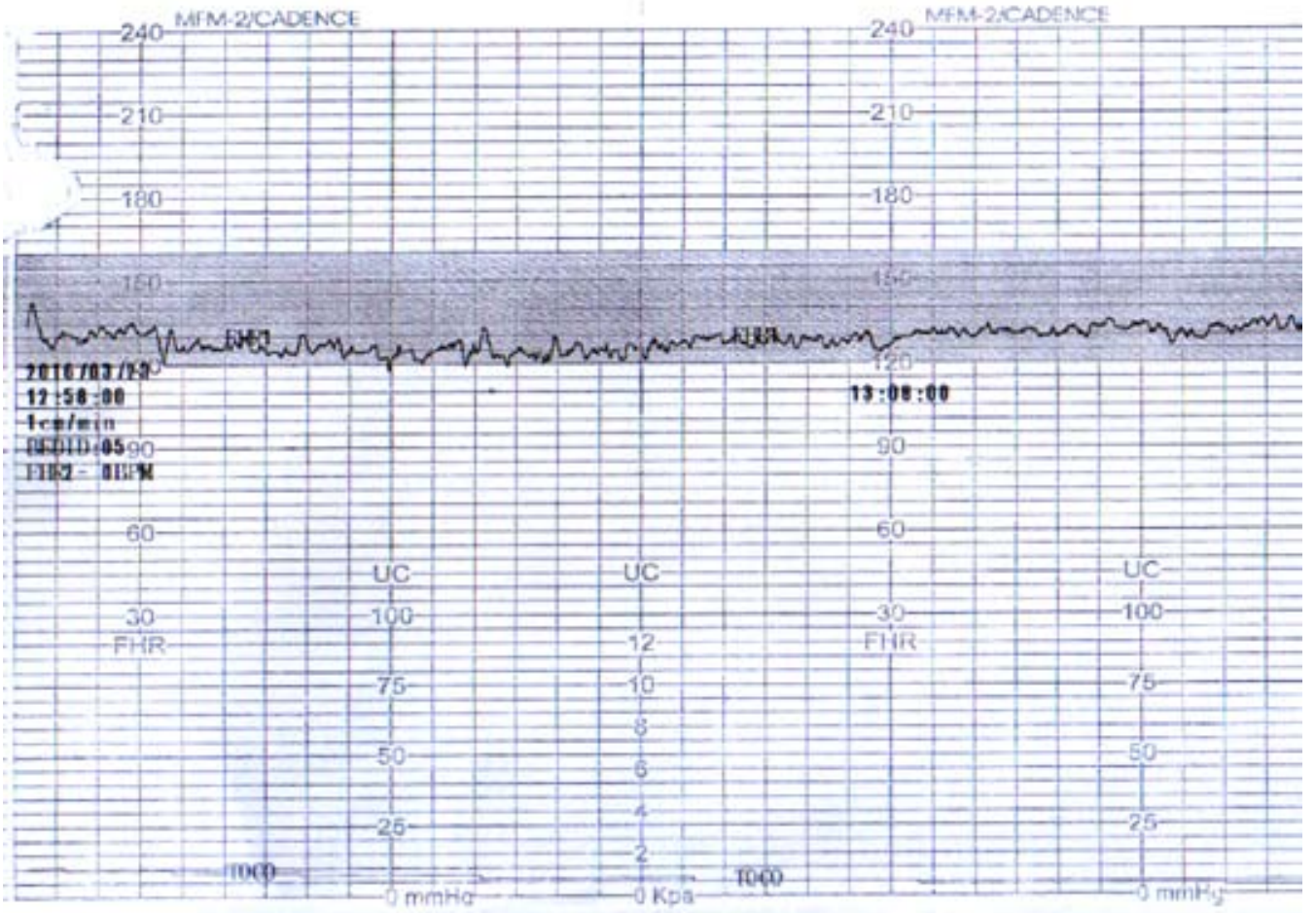

Рис. 2. Вагітність 33 тижні. Оцінка КТГ - 7 балів. 
Таблиця 1. Оцінка кардіотокограм у вагітних із затримкою росту плода

\begin{tabular}{|c|c|c|c|}
\hline \multicolumn{2}{|c|}{ Показник } & $\begin{array}{c}\text { Основна група } \\
\text { n=30 }\end{array}$ & $\begin{array}{c}\text { Контрольна група } \\
\text { n=25 }\end{array}$ \\
\hline \multicolumn{2}{|c|}{ Базальний ритм, уд./хв } & $128,2 \pm 2,44^{*}$ & $142,5 \pm 2,45^{\star}$ \\
\hline \multirow{2}{*}{ Варіабельність } & амплітуда, уд./хв & $6,16 \pm 0,22^{*}$ & $18,9 \pm 0,16^{*}$ \\
\hline & частота за 1 хв & $3,21 \pm 0,15^{*}$ & $6,34 \pm 0,18^{*}$ \\
\hline \multicolumn{2}{|c|}{ Акцелерації за 30 хв } & $1,52 \pm 0,03^{*}$ & $7,91 \pm 0,11^{*}$ \\
\hline \multicolumn{2}{|c|}{ Децелерації за 30 хв } & Спонтанні, ранні & Відсутні \\
\hline
\end{tabular}

Примітка. * - р1<0,05 достовірність у порівнянні 3 контрольною групою.

На основі проведеного аналізу кардіотокограм виявлено, що базальний ритм у вагітних із затримкою росту

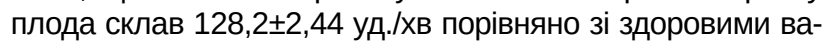
гітними $142,5 \pm 2,45$ уд./хв $(P<0,01)$. Варіабельність частоти за 1 хвилину у вагітних із затримкою росту до лікування склала $3,21 \pm 0,15$, що $€$ достовірно нижчою порівняно 3 контрольною групою $(6,34 \pm 0,18)$. Аналізуючи кардіотокограми, звернули увагу та те, що акселерації виявлялись у вагітних із затримкою росту у $67,2 \%$, у здорових вагітних у

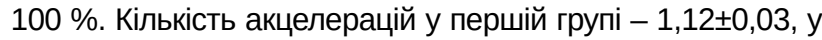
здорових $-4,91 \pm 0,11$. Кардіотокограми вагітних із затримкою росту плода характеризуються спонтанними ранніми децелераціями та монотонним ритмом. 3 метою діагностики внутрішньоутробного стану плода з затримкою росту виділили критерії, які свідчать про початкові ознаки страждання плода: зменшення амплітуди осциляцій менше 5 уд./хв, зниження кількості акцелерацій до 3 і менше та поява спонтанних децелерацій. Такі ознаки, як зниження амплітуди осциляцій менше 3 уд./хв, відсутність акцелерацій, поява децелерацій, свідчать про виражені ознаки гіпоксії плода.

При аналізі кардіотокограсрічних показників виявлена достовірна відмінність у вагітних із ЗРП ступеня порів- няно з жінками контрольної групи. Діагностовано значне зниження довжини стабільного ритму і суттєві порушення реакцій акцелерації. Звертає на себе увагу збільшення кількості, тривалості і глибини децелерацій. Все це свідчить про зниження реактивності серцево-судинної системи плода і $€$ характерною ознакою гіпоксії.

Таким чином, при аналізі кардіотокограм виявлено відмінності вагітних із затримкою росту плода порівняно зі здоровими вагітними, що свідчить про порушення фетоплацентарного кровообігу та наявність плацентарної дисорункції.

Висновки. 1. Кардіотокограми у вагітних із затримкою росту плода характеризуються достовірним зменшенням базальної частоти серцевих скорочень плода, пониженою амплітудою, зменшенням кількості акцелерацій, наявністю децелерацій.

2. Отримані результати свідчать про зниження реактивності серцево-судинної системи плода з затримкою росту і $€$ характерною ознакою гіпоксії.

ПЕРСПЕКТИВИ ПОДАЛЬШИХ ДОСЛІДЖЕНЬ. РОЗробка та впровадження методик лікування затримки росту плода у вагітних з проведенням кардіотокографії.

\section{СПИСОК ЛІТЕРАТУРИ}

1.Gardosi J. Preventing stillbirths through improved antenatal recognition of pregnancies at risk due to fetal growth restriction / J. Gardosi// Public Health. - 2014. -Vol. 128, № 8. - P. 698-702.

Barker D. J. Placental programming of chronic diseases, cancer and lifespan: a review / D. J. Barker, K. L. Thornburg // Placenta. - 2013. - Vol. 34, № 10. - P. 841-845.

Ritz E. Prenatal programming-effects on blood pressure and renal function / E. Ritz // Nat. Rev. Nephrol. - 2011.Vol. 7, № 3. - P. 137-144.

Sebire N. J. Correlation of placental pathology with prenatal ultrasound findings / N. J. Sebire, W. Sepulveda // J. Clin. Pathol. - 2008. - Vol. 61, № 12. - P. 1276-1284.

5. Даниленко А. І. Особливості періоду адаптації ново- народжених та дітей першого року життя з гіпоксією та затримкою внутрішньоутробного розвитку / А. І. Даниленко, Н. М. Рожковська, В. О. Ситнікова // Патологія. - 2005. № 3. - C. 64 .

6. Маркін Л. Б. Діагностично-профрілактичні заходи при затримці функціонального диференціювання плаценти / л. Б. Маркін, О. О. Михайлів // Педіатрія, акушерство та гінекологія. - 2008. - № 5. - С. 63-67.

7. Воскресенский С. Л. Оценка состояния плода. Кардиотокограсрия. Допплерометрия. Биосризический профиль / С. Л. Воскресенский. - Мн. : Книжный дом, 2004.

8. Про затвердження клінічних протоколів з акушерської та гінекологічної допомоги : наказ МОЗ України від 15.07.11 № 417. 